\title{
Adsorption of the R-specific Bacteriophage PR4 to Pili Determined by a Drug Resistance Plasmid of the W Compatibility Group
}

\author{
By D. E. BRADLEY \\ Faculty of Medicine, Memorial University of Newfoundland, \\ St John's, Newfoundland, Canada $A$ I $C{ }_{5} S_{7}$
}

(Received I2 January 1976)

\section{INTRODUCTION}

Bacteriophages PR4 (Stanisich, 1974; Bradley, 1974) and PRDI (Olsen, Siak \& Gray, I974) represent a new type of phage which lyses species of bacteria harbouring drug resistance plasmids of either the $\mathrm{P}, \mathrm{N}$ or $\mathrm{W}$ compatibility groups. Both viruses contain lipid and double-stranded DNA. PR4 has a head (diameter $65 \mathrm{~nm})$ and a short tail $(60 \mathrm{~nm})$ which is not usually visible. PRDI appears similar but lacks a tail. Both phages were thought to adsorb directly to the bacterial cell wall rather than to plasmid-determined pili. This hypothesis was based chiefly on electron microscopic observations which revealed virions attached to the cell surface of bacteria carrying the P group plasmid RPI (Olsen et al., I974; Bradley \& Rutherford, I975); the virions were not obviously attached to RPI pili. Secondly, the receptors for PR4 and N-specific filamentous phage Ike appear to be produced at a derepressed level (Dennison \& Baumberg, 1973), and yet no pili have been found for $\mathrm{N}$ group plasmids. This implies that both types of receptor are not pili, otherwise the filaments would have been visible in the electron microscope.

The adsorption of PR4 and PRDI to bacteria harbouring W plasmids, and therefore carrying W-pili (Bradley, I975), has not been studied using the electron microscope. The present communication describes the unexpected attachment of PR4 virions to the tips of W-pili.

\section{METHODS}

Bacteria and bacteriophages were very kindly supplied as follows: Salmonella typhimurium LT2 strain SQII39 by Rosemary Bradley; Escherichia coli CR34 (Olsen \& Shipley, 1973) by R. H. Olsen; the donor strain E. coli $\mathrm{J}_{53}(\mathrm{Sa})$, formerly written $\mathrm{J} 53 \mathrm{~S}-\mathrm{a}$, by G. Jacoby; E. coli J53(Sa-I) by N. Datta; and phage PR4 by V. Stanisich. The R factor Sa (Watanabe, Furuse \& Sakaizumi, 1968 ) is the 'type' plasmid of the $\mathrm{W}$ compatibility group and Sa- I is a Traderivative (Hedges \& Jacob, 1974). $\mathrm{Sa}^{+}$strains were constructed by standard mating procedures; E. coli $\mathrm{CR}_{34}$ (Sa-I) by mobilization using the plasmid RPI ; and $\mathrm{Sa}^{-}$revertants by selecting clones resistant to phage PR4 from soft-agar plates of E. coli CR34(Sa) confluently lysed by the phage.

Preparation and electron microscopy of adsorption mixtures of bacteria and phage. Bacteria were grown overnight at $37^{\circ} \mathrm{C}$ in static Nutrient Broth (Difco) cultures which produced particularly large numbers of W-pili. A sample $(0.2 \mathrm{ml})$ of culture was mixed with an equal volume of phage $\mathrm{PR} 4$ suspension in broth (titre about $\mathrm{I} \times \mathrm{IO}^{10}$ plaque-forming units $/ \mathrm{ml}$ ) and incubated (static) at $37^{\circ} \mathrm{C}$ for 5 to $10 \mathrm{~min}$. Bacteria were mounted for electron microscopy by touching a specimen grid (coated with a carbon film) on to the surface of the culture, followed by washing, and negative staining in $0.2 \%(\mathrm{w} / \mathrm{v})$ sodium phosphotungstate solution. 
Phages adsorbed to random cells were then counted. When phages were being counted on the cell surface, virions were only scored if they were in contact with the cell periphery, since those on the body were liable to be obscured by negative staining material. This procedure gave reproducible results, but was only suitable for comparative studies as described below. It did not give an indication of the absolute numbers of adsorbed virions. Similarly, pili were only counted if they projected beyond the edge of the cell.

\section{RESULTS}

When specimens prepared from adsorption mixtures of phage $\mathrm{PR}_{4}$ and $S$. typhimurium SQI I39(Sa) at a multiplicity of infection of 50 phages/bacterium were examined by electron microscopy, it was found that about $30 \%$ of the W-pili bore a single PR4 virion attached to their tips (Fig. I). Very few of the phages on the pili (two out of about 50) were apparently attached to the sides (Fig. I, top virion), and only one pilus was observed to have more than one virion (Fig. 2). A close examination of this micrograph suggests that the two virions are probably stuck together, with only one adsorbed to the filament. The empty PR4 virion exhibits its characteristic thick lipid layer (Bradley \& Rutherford, 1975). Adsorbed virions were not all full as in Fig. I; empty particles were also found attached to the pili (Fig. 3). No phage tails were visible. It was noted that $\mathrm{PR}_{4}$ adsorption was accompanied by a $90 \%$ reduction in the number of pili present relative to that in an uninfected control.

Virions attached to W-pili constituted the minority of adsorbed phages. The majority appeared at the cell surface as was originally observed for bacteria carrying the plasmid RPI (Bradley, 1974; Olsen et al., I974; Bradley \& Rutherford, 1975). In a sample of 100 cells, 53I virions were counted at the cell periphery and only 13 at the tips of W-pili. To ensure that the adsorption of phages to the cell wall was specific (confined to $\mathrm{Sa}^{+}$strains), the following test was carried out. Virions adsorbed to the cell surface (multiplicity of infection, 80 phages/bacterium) were counted on $E$. coli strains $\mathrm{CR} 34(\mathrm{Sa})$, a corresponding $\mathrm{Sa}^{-}$ revertant without pili (see Methods), and a strain of CR34 carrying the plasmid Sa-I, which is PR4-resistant and has no W-pili (Bradley \& Cohen, unpublished results). The average numbers of PR4 virions on CR34(Sa-I) and the $\mathrm{Sa}^{-}$revertant were 0.88 and 0.66 phages/cell respectively. These figures are considered to represent the non-specific adhesion of the phages to the cell surface. With CR34(Sa), there were $5 \cdot I 8$ phages/cell. Thus PR4 adsorbs specifically to the surface of strains with W-pili, and not to those without them, even though the strain carrying the plasmid Sa-I has other characteristics of the parent plasmid.

The adsorption of phage $\mathrm{PR}_{4}$ to $E$. coli $\mathrm{CR} 34(\mathrm{Sa})$ caused a large reduction in the number of pili, from an average of $\mathrm{I} \cdot \mathrm{O}$ pili/cell in uninfected cultures to only $0 \cdot 04$ pili/cell in infected cultures. For this reason pili with phages at their tips were extremely rare.

\section{DISCUSSION}

At least 50 examples of $\mathrm{PR}_{4}$ virions adsorbed to the tips of W-pili were seen on S. typhimurium SQI I39(Sa) in the course of this investigation. The absence of phages on the sides of the pili is, in itself, virtually conclusive evidence of specificity. This does not necessarily mean that W-pili are the means of $\mathrm{PR}_{4}$ DNA penetration into the cell. The existence of large numbers of virions at the cell surface seems to contradict this. However, these observations are very similar to those described for some pilus-dependent tailed bacteriophages of Pseudomonas aeruginosa (Bradley, 1973 a; Bradley \& Pitt, 1974) which adsorbed to the sides of retractile pili (Bradley, 1972). With these phages, numerous virions were found on the 


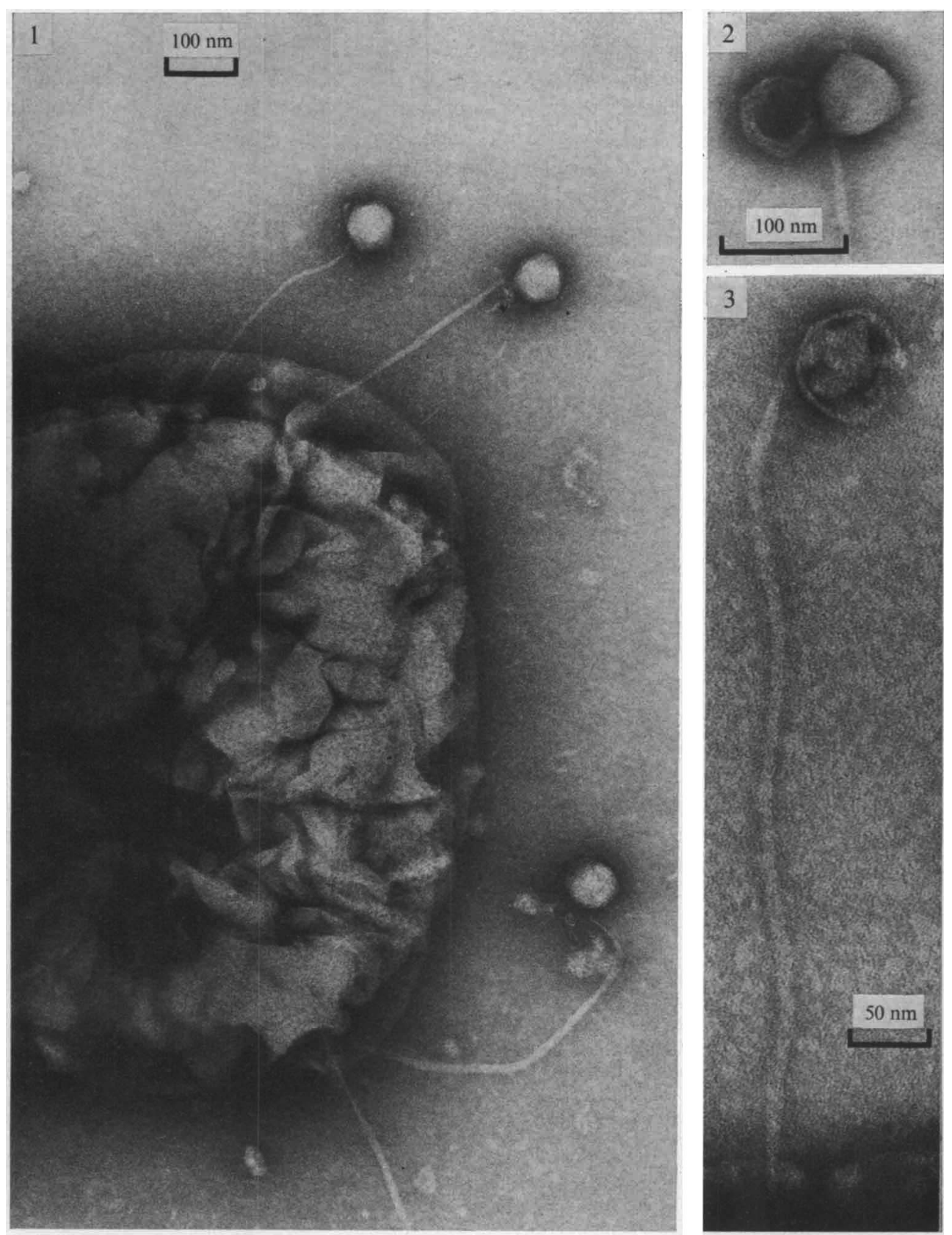

Fig. I. PR4 virions attached to W-pili on S. typhimurium SQI I39(Sa). The top one seems to be adsorbed to the side of the pilus near the tip, but this is a drying effect, the real point of attachment being the upper left apex. Virions adsorbed to the surface were located elsewhere on the cell.

Fig. 2. Two virions apparently attached to a single W-pilus.

Fig. 3. An empty virion adsorbed to a W-pilus tip. 
surface of sensitive cells as well as on the sides of pili. The observations suggested an adsorption sequence in which the phages became attached to the pili, which then retracted into the cell pulling the virions to the surface where DNA injection could take place (Bradley \& Pitt, I974). The present circumstances differ in that phage PR4 adsorbs to the tips rather than to the sides of the pili; nevertheless a similar sequence of events is suggested. This model is particularly attractive since the W-pili would have to withdraw completely into the cell in order to transport the virions to the surface, and this would explain the disappearance of most of the pili. It is possible that a secondary receptor, which would trigger DNA injection, could be located in the cell wall as suggested for phage PRDI by Siak \& Olsen (1975). With an adsorption sequence such as this, one would not expect to see any pili with phages attached since they would all have supposedly retracted. One obvious explanation for the presence of phage plus pilus complexes is that the pilus retraction mechanism failed in some cases. Alternatively, the sodium phosphotungstate negative stain in which the pili were embedded could have solidified before they were able to retract. In either case only a small number of pili with virions attached would be expected, as was found in the present study. The pili without attached phages ( $70 \%$ of the total number) probably grew towards the end of the adsorption period so had not been extended for sufficient time to receive a virion. Another possibility is that they grew during mounting and washing when virions were absent.

The only other bacteriophages which adsorb to pilus tips are the filamentous types, and their mechanism of penetration is basically similar to that proposed for PR4 (Jacobson, 1972; Bradley, I973b). PR4 is the only isometric phage with this adsorption site. The role of the tail in the adsorption sequence has yet to be determined. The above observations suggest that $\mathrm{PR}_{4}$ is pilus-dependent, in which case it would adsorb to three different types of pilus receptor determined by plasmids of the $\mathrm{P}, \mathrm{N}$ and $\mathrm{W}$ compatibility groups. W-pili are morphologically quite different to P group RPI pili (Bradley, 1974), and the elusive N-pili may be too short to be obvious in the electron microscope. This possibility is being investigated.

This work was supported by the Medical Research Council of Canada, grant no MA5608. The author is very grateful to Rosemary Bradley for reading the manuscript, and to Doris Cohen for valuable technical assistance.

\section{REFERENCES}

Bradley, D. E. (1972). Shortening of Pseudomonas aeruginosa pili after RNA-phage adsorption. Journal of General Microbiology 72, 303-319.

Bradley, D. E. (1973a). Basic characterization of a Pseudomonas aeruginosa pilus-dependent bacteriophage with a long non-contractile tail. Journal of Virology 12, I I 39-I 148.

Bradley, D. E. (1973 b). The adsorption of the Pseudomonas aeruginosa filamentous bacteriophage Pf to its host. Canadian Journal of Microbiology i9, 623-631.

BradLeY, D. E. (I974). Adsorption of bacteriophages specific for Pseudomonas aeruginosa R factors RPI and RI 822. Biochemical and Biophysical Research Communications 57, 893-900.

BradLEY, D. E. (I975). The occurrence of pili associated with a plasmid of the W compatibility group. Biochemical and Biophysical Research Communications 64, 918-925.

Bradley, D. E. \& Pitr. T. L. (1974). Pilus-dependence of four Pseudomonas aeruginosa bacteriophages with non-contractile tails. Journal of General Virology 24, I-1 5.

Bradley, D. E. \& Rutherford, E. L. (I975). Basic characterization of a lipid-containing bacteriophage specific for plasmids of the $\mathrm{P}, \mathrm{N}$ and $\mathrm{W}$ compatiblity groups. Canadian Journal of Microbiology 21, 152I63.

DenNison, S. \& BAUMBerg, S. (I973). N plasmid transfer in Escherichia coli and adsorption of the N-specific filamentous phage, Ike. Proceedings of the Society for General Microbiology $\mathbf{1}$, Io.

Hedges, R. W. \& JACOB, A. E. (I974). Transposition of ampicillin resistance from RP4 to other replicons. Molecular and General Genetics 132, $3 \mathrm{I}-40$.

JACOBSON, A. (1972). Role of F pili in the penetration of bacteriophage fi. Journal of Virology 10, 835-843. 
Olsen, R. H. \& Shipley, P. (1973). Host range and properties of the Pseudomonas aeruginosa R factor Ri822. Journal of Bacteriology I13, 772-780.

Olsen, R. H., SIAK, J. \& GRAY, R. H. (I974). Characteristics of PRDi, a plasmid-dependent broad host range DNA bacteriophage. Journal of Virology 14, 689-699

SIAK, J. \& OLSEN, R. H. (1975). R plasmid encoded PRDI duplex DNA phage cell wall receptor. Abstracts of the Annual Meeting of the American Society for Microbiology, p. 259. Washington: American Society for Microbiology.

STANISICH, V. (1974). The properties and host range of male-specific bacteriophages of Pseudomonas aeruginosa. Journal of General Microbiology 84, 332-342.

Watanabe, T., Furuse, C. \& Sakaizumi, S. (1968). Transduction of various R factors by phage PI in Escherichia coli and by phage $\mathbf{P} 22$ in Salmonella typhimurium. Journal of Bacteriology 96, I791-1 795. 